\title{
WSPÓŁCZESNE WYZWANIA PEDAGOGIKI PRZEDSZKOLNEJ I SZKOLNEJ W OBSZARZE EDUKACJI WŁĄCZAJĄCEJ DZIECI NIEWIDOME I SŁABOWIDZĄCE
}

\begin{abstract}
Streszczenie: Artykuł ma na celu przybliżenie modelu edukacji włączającej dzieci niewidome i słabowidzące w placówkach przedszkolnych i szkolnych, zgodnie ze strategią normalizacji i założeniami współczesnej tyflopedagogiki. Wyjaśnia znaczenie podstawowych uwarunkowań dydaktyczno-metodycznych, organizacyjnych i społecznych oraz podkreśla rolę wczesnego wspomagania rozwoju dla jakości inkluzji dzieci z niepełnosprawnością wzroku w systemie kształcenia ogólnodostępnego.
\end{abstract}

Słowa kluczowe: dziecko, niepełnosprawność wzroku, edukacja włączająca, przedszkole, szkoła.

\section{Wprowadzenie}

Warunkiem efektywnej inkluzji edukacyjnej jest właściwa edukacja rodziców i ich dzieci o zróżnicowanym rozwoju, dobry poziom zrehabilitowania ogólnego dziecka z niepełnosprawnością wzroku, prowłączające postawy społeczne, profesjonalne merytoryczne przygotowanie nauczycieli i wychowawców, przygotowanie odpowiedniej infrastruktury przedszkola i szkoły (zarówno przedszkola, jak i szkoły muszą być dostosowane do potrzeb podopiecznych o zróżnicowanych potrzebach) oraz zbudowanie właściwego systemu wsparcia na rzecz dziecka niewidomego czy słabowidzącego przez wszystkie podmioty uczestniczące w tym procesie (Dycht 2015).

Włączanie - realizowane zgodnie z ideą normalizacji - obejmuje szereg instytucjonalnych i pozainstytucjonalnych działań, umożliwiających osobom o zróżnicowanym rozwoju zdobywanie normalnych doświadczeń życiowych, statusu społecznego i warunków życia, uznawanych za standardowe dla danej społeczności (Sekułowicz 2017). Celem tego typu starań jest stworzenie tym osobom takich 
samych warunków funkcjonowania, jak osobom o typowym rozwoju (Speck 2005; 2013; Szumski 2010; 2011).

W tym artykule wskazano na rolę i znaczenie realizacji modelu normalizacyjnego jako podstawy edukacji włączającej i stymulowania rozwoju dziecka $\mathrm{z}$ niepełnosprawnością wzroku w wieku przedszkolnym i szkolnym. Zwrócono również uwagę na uwarunkowania tego procesu, decydujące o jakości włączania dziecka niewidomego i słabowidzącego w system ogólnodostępny, realizowany na etapie edukacji przedszkolnej i szkolnej. Współcześnie pojęta pedagogika przedszkolna, odpowiadając na aktualne wyzwania społeczne, musi dostrzegać wartość, jaką wnosi odpowiednio wczesna i właściwie zaprojektowana interwencja dla optymalizacji rozwoju dziecka $\mathrm{z}$ niepełnosprawnością oraz dla jakości wsparcia edukacyjno-terapeutycznego proponowanego w ogólnodostępnych placówkach przedszkolnych i szkolnych.

\section{Uwarunkowania procesu włączania dzieci z niepełnosprawnością wzroku w przedszkolach i szkołach ogólnodostępnych}

Włączanie dzieci z niepełnosprawnością, w tym także wzrokową, do przedszkoli czy szkół ogólnodostępnych to proces odpowiedzialny, rzutujący nie tylko na efektywność ich dalszej edukacji, ale również - a może nawet przede wszystkim - na całokształt przyszłych relacji społecznych i późniejszą jakość życia. Dzieci niewidome lub z głęboką słabowzrocznością od urodzenia lub wczesnego dzieciństwa potrzebują adekwatnej, właściwej ich preferencjom, możliwie wczesnej i profesjonalnej interwencji ze strony środowiska rodzinnego oraz instytucji specjalistycznych zajmujących się pomocą rehabilitacyjno-edukacyjną. Rozwój i dalsze godne życie dziecka $\mathrm{z}$ dysfunkcją wzroku, bez specjalnego wsparcia w sytuacji pozbawienia lub poważnego ograniczenia aktywności poznawczej oraz kontaktów ze światem i ludźmi, często pozostawia takie dziecko na najniższych szczeblach funkcjonowania.

Warto zaznaczyć, że włączanie nie dotyczy tylko dzieci z trudnościami rozwoju jest skierowane do wszystkich dzieci wymagających specjalnego wsparcia (nie tylko do tych doświadczających niepełnosprawności: wzroku, słuchu, ruchu, wielorakiej niepełnosprawności (o wysokim poziomie funkcjonowania) - beneficjentami tego wsparcia mogą być również dzieci z odmienną specyfiką funkcjonowania poznawczo-percepcyjnego: dzieci o wyższych (wybitnie zdolne i uzdolnione) lub niższych niż przeciętne możliwościach intelektualnych (z niepełnosprawnością intelektualną, z trudnościami uczenia się, jak dysleksja, dysgrafia, dysortografia, dyskalkulia), z autystycznym spektrum zaburzeń i z zespołami psychozopodobnymi, z przewlekłą chorobą, z zaburzeniami mowy, niedostosowane społecznie lub zagrożone, zaniedbane środowiskowo, doświadczające trudności adaptacyjnych związanych z różnicami kulturowymi (reemigrujące, cudzoziemskie). Ponadto chodzi o docenianie i wspieranie różnorodności wszystkich uczniów i dobro 
wszystkich dzieci i ich rodzin biorących udział we włączaniu - zatem potrzeby dzieci o prawidłowym rozwoju są równie ważne i nie mogą być pomijane. Bengt Lindquist, specjalny sprawozdawca Narodów Zjednoczonych ds. standardowych zasad wyrównywania szans osób niepełnosprawnych, twierdzi, że „szkoła dobra dla dzieci ze specjalnymi potrzebami jest lepszą szkołą dla wszystkich" (za: Firkowska-Mankiewicz 2004, s. 19). Z kolei Wiktor Lechta (2010, s. 325) pisze: „w przypadku pedagogiki inkluzyjnej chodzi bowiem o inną jakość niż integracja: o bezwarunkowe zaakceptowanie specjalnych potrzeb wszystkich dzieci”. Konieczne jest zatem stworzenie w szkołach powszechnych takiego klimatu kulturowego, który pozwoli im bardziej elastycznie odpowiadać na potrzeby wszystkich dzieci danej społeczności. Tylko takie rozumienie idei inkluzji stwarza szansę wypracowania najbardziej optymalnego modelu wsparcia poprzez edukację. Buduje świadomość społeczną wszystkich podmiotów dyskursu edukacyjnego.

Jest to proces, który nie odbywa się automatycznie poprzez sam fakt bycia takiego dziecka w przedszkolu czy szkole. Normalizacja bowiem to nie tylko stan, jaki chcemy osiągnąć, ale także proces dochodzenia do niego. Wymaga właściwego przygotowania, zarówno na płaszczyźnie mentalnej, jak i infrastrukturalnej czy metodyczno-dydaktycznej, jak również wykorzystania możliwości osobowościowych, rozwojowych dziecka włączanego w ten proces, dużego potencjału i aktywności jego rodziny oraz uwzględnienia zasobów instytucji zaangażowanych w edukację inkluzyjną.

Aby ideę edukacji włączającej wcielić w życie i żeby odbywało się to z korzyścią dla wszystkich dzieci uczestniczących w edukacji przedszkolnej i szkolnej, muszą być spełnione do tego opisane poniżej warunki.

Wspierająca rola wczesnego wspomagania rozwoju dziecka

Wspomaganie rozwoju dziecka z niepełnosprawnością wzroku i jego rodziny $\mathrm{w}$ procesie wczesnej interwencji jest jednym $\mathrm{z}$ komponentów wspierających strategię inkluzyjną - nie tylko w odniesieniu do obszaru edukacji, to pewna filozofia myślenia, która w oparciu o paradygmat normalizacyjny nierozerwalnie wiąże się z budowaniem autonomii osób o zróżnicowanym rozwoju. Kształtowanie autonomii buduje zaś poczucie własnej niezależności, odrębności czy samodzielności tych osób. Dlatego, im wcześniejsza i efektywniejsza będzie współpraca zespołu specjalistów w obszarze wspierania niewidomego lub słabowidzącego dziecka, tym sprawniejsze będzie zapobieganie jego niepowodzeniom społecznym w późniejszych etapach życia.

Narodziny dziecka są zwykle podniosłym i radosnym wydarzeniem w życiu rodziny. Niestety, sytuacja ta często ulega zmianie, gdy przychodzi na świat dziecko $\mathrm{z}$ dysfunkcją wzroku, słabowidzące lub niewidome. $U$ dorosłych pojawia się wtedy cała gama uczuć ambiwalentnych, zarówno pozytywnych, jak i negatywnych, skierowanych i na samo dziecko, i na własną rolę jako rodzica (Urmańska 2007). Często 
rodzice przeżywają żałobę po pełnosprawnym dziecku, którego reprezentację mieli w swojej psychice przed rozpoznaniem trudności. Cierpią, a cierpienie to będzie wywoływało sprzeczne dążenia - z jednej strony chęć przywrócenia dziecku wzroku za wszelką cenę, z drugiej strony zaś nabranie dystansu emocjonalnego wobec niewidzenia dziecka. Mechanizmy te, zdaniem Wandy Urmańskiej, służą zmniejszeniu odczuwanego cierpienia. Rodzice mogą także zaprzeczać niepełnosprawności dziecka lub usilnie szukać coraz to nowych metod i lekarzy, aby przywrócić dziecku wzrok. Mogą też stawiać dziecku nadmierne wymagania, nierespektując jego ograniczonych możliwości wzrokowych, co w znacznym stopniu utrudnia prawidłowy rozwój dziecka. Obecność tych postaw wyraźnie podkreśla się w piśmiennictwie tyflologicznym (Orkan-Łęcka 2003; Sińska 2006; Wawrowska 2011).

W szczególnie silny sposób mogą odczuwać brak kompetencji w opiece nad niewidomym czy słabowidzącym dzieckiem. Nie mogą także w pełni skorzystać z podpowiedzi i porad dziadków czy znajomych, którym obce jest podobne doświadczenie. Dodatkowo dzieci z dysfunkcją wzroku są znacznie bardziej wymagającymi partnerami relacji z rodzicami niż dzieci prawidłowo widzące (Skoczylas 2013). Przed rodzicami pojawia się więc specjalne zadanie - nauczenia się sygnałów, które daje dziecko i dawania mu możliwych do odczytania przez nie odpowiedzi. Wyzwaniem staje się stworzenie z dzieckiem wspólnego ,języka”, wspólnej strategii komunikacji.

Aby zaakceptować siebie w roli rodzica niepełnosprawnego wzrokowo dziecka, niezbędne jest wsparcie i profesjonalna pomoc. Potrzebne jest uświadomienie rodzicom pewnych psychologicznych prawidłowości i pomoc w adaptacji do niełatwej roli rodzica dziecka niepełnosprawnego wzrokowo. Rodzice dzieci niewidomych i słabowidzących, którzy znaleźli się w trudnej sytuacji w związku z pojawieniem się dziecka z niepełnosprawnością w rodzinie, potrzebują wsparcia specjalistów, którzy podzielą się z nimi swoją wiedzą, doświadczeniem i umiejętnościami terapeutycznymi, będą pomocą w zakresie budowania relacji rodzice-dziecko, więzi rodzinnych i kompetencji rodzicielskich. Opiekunowie dziecka niepełnosprawnego wzrokowo, chcąc zaadaptować się do nowych zadań, powinni zapoznać się z fachową lekturą okulistyczną i tyflologiczną, ale także stworzyć przestrzeń do wzajemnego wyrażania i przepracowywania emocji: rozmawiać o niepełnosprawności wzroku z najbliższym otoczeniem i podejmować inne aktywności, które mają im pomóc stać się dobrymi rodzicami, rozwijającymi swój własny, unikalny styl rodzicielski w opiece i wychowaniu dziecka niewidomego lub słabowidzącego.

Konieczna jest do tego celu nie tylko zmiana mentalna i emocjonalna, lecz przede wszystkim wiedza i kompetencje, które można nabyć. Pomocne będą także wizyty u lekarzy; warto skorzystać z pomocy psychologa, tyflopedagoga, grup wsparcia rodziców dzieci niepełnosprawnych wzrokowo. Uczestnictwo w nich może być bardzo cenne, wymiana doświadczeń pozwoli nie tylko zredukować stres i uzyskać większy dystans do własnej sytuacji, lecz także zdobyć potrzebną wiedzę, aby rozwój dziecka był optymalny, a ono samo - szczęśliwe (Barańska 2007; Pisula 2007). 
Rodzice, którzy skupiają uwagę na możliwościach i zdolnościach dziecka, a nie na jego niepełnosprawności wzrokowej, w sposób bardziej racjonalny i zorganizowany wspomagają jego rozwój. Uwzględniają indywidualne potrzeby wszystkich członków rodziny, jak i jej dobro jako całości. Pozwalają dziecku na autonomię i stymulują jego rozwój w ramach jego indywidualnych możliwości. Umieją obiektywnie spojrzeć zarówno na samo dziecko, jak i na sytuację całej rodziny (Czerwińska 2016). Przyjęcie takiej postawy jest możliwe tylko wtedy, gdy rodzice świadomie decydują się na nabywanie wiedzy i umiejętności niezbędnych do zrozumienia specyfiki rozwoju małego dziecka z dysfunkcją wzroku. Ten proces dojrzewania do odpowiedzialnego pełnienia funkcji rodzicielskich będzie trwał całe życie, podlegał prawu ewolucji - wraz z kolejnymi cyklami życia rodziny i indywidualnym rozwojem dziecka $\mathrm{z}$ dysfunkcją wzroku.

W obszarze wczesnego wspomagania rozwoju dziecka w środowisku rodzinnym istotne jest zwiększanie kompetencji specjalistów (tyflopedagog, psycholog, logopeda, terapeuta, rehabilitant) zatrudnionych w placówkach realizujących wczesne wspomaganie rozwoju dziecka (WWRD) w zakresie współpracy i budowania koalicji na rzecz małego dziecka $\mathrm{z}$ niepełnosprawnością wzroku oraz doskonalenie ich umiejętności diagnostycznych, interpersonalnych, organizacyjnych i terapeutycznych (Walkiewicz 2005). W konsekwencji możliwe jest przygotowanie przez placówki realizujące wczesną interwencję coraz lepszej jakościowo oferty dla małego dziecka z niepełnosprawnością wzroku i dla jego rodziny.

\section{Odpowiednio poinformowani i przygotowani rodzice}

Kompetentne - rzetelne i pełne - przygotowanie rodzica: informacyjne (tyflologiczne) i mentalne (pełna akceptacja niepełnosprawności wzrokowej dziecka) ma decydujące znaczenie w momencie podejmowania decyzji o typie placówki przedszkolnej czy szkolnej - ogólnodostępnej czy specjalnej, tworzonej wyłącznie z myślą o potrzebach dzieci niewidomych lub słabowidzących. Wybór najodpowiedniejszej opcji dla dziecka przestaje być problemem. Rodzice wiedzą wówczas, na jakie uwarunkowania szkolne należy zwrócić uwagę, aby spełniały ich oczekiwania, jak i preferencje ich niepełnosprawnego wzrokowo dziecka. Potrafią wybrać najbardziej optymalną ofertę edukacyjną, której aktualnie potrzebują. Dzieci z niepełnosprawnością wzroku, biorące udział w procesie wczesnej interwencji, wykazują zwykle wysoki poziom ogólnego zrehabilitowania, są samodzielne i świadome swoich możliwości percepcyjnych. Dzieci z dysfunkcją wzroku i ich rodziny, uczestniczące w zespołach WWRD, stają się tym samym aktywnymi i kompetentnymi podmiotami w obszarze współpracy z przedszkolem czy szkołą powszechną. Istotne jest wówczas nie tyle nawiązanie jakiejkolwiek współpracy zespołu specjalistów z rodziną dziecka doświadczającego niepełnosprawności wzroku w placówce edukacyjnej, ile doskonalenie poziomu tej współpracy (Czerwińska, Dąbrowska 2015). 
Warto w tym miejscu zwrócić uwagę na konieczność udzielenia także rodzicom dzieci pełnosprawnych szczegółowych informacji o funkcjonowaniu psychospołecznym dziecka z dysfunkcją wzroku i organizacji jego edukacji w grupie przedszkolnej lub klasie ogólnodostępnej. Powinni oni wyrazić zgodę na włączenie dziecka z dysfunkcją wzroku w całą grupę społeczną. Dostęp do wiarygodnej, pełnej informacji sprzyja eliminowaniu stereotypowych, nierzadko krzywdzących poglądów na temat niepełnosprawności wzroku, mających wpływ na niewłaściwe postawy społeczne, sprzyjające dyskryminacji czy wykluczeniu społecznemu tej grupy osób. Piszą na ten temat: Janusz Kirenko, Piotr Grindrich (2007), Joanna Konarska (2010), Jadwiga Kuczyńska-Kwapisz (2014), Małgorzata Paplińska, Joanna Witczak-Nowotna (2015). Rolę tyfloedukacji, upowszechniającej wiedzę na temat potrzeb i możliwości osób z dysfunkcją wzroku, ograniczającej uprzedzenia wśród dzieci i młodzieży pełnosprawnej podkreśla m.in. program Finding Out about Blindness - Teacher's Pack (1991). Pomaga on przygotować osoby widzące do współuczestnictwa z osobami z niepełnosprawnością wzroku, kształtować postawy otwartości, zrozumienia i akceptacji.

Dobry poziom zrehabilitowania ogólnego dziecka z niepełnosprawnością wzroku

Istotnym warunkiem efektywnej edukacji inkluzyjnej dzieci z dysfunkcją wzroku jest normalny rozwój intelektualny tych dzieci, umożliwiający im logiczne myślenie i rozwój mowy. Aby dziecko niewidome lub słabowidzące mogło osiągać właściwy poziom sprawności intelektualnych, konieczna jest prawidłowa działalność pozostałych analizatorów, a zwłaszcza dotyku i słuchu, dzięki którym mogą wytworzyć się kompensacyjne układy strukturalne. Zdarza się jednak, że także dzieci głuchoniewidome o normalnej sprawności intelektualnej i wysokim poziomie funkcjonowania, które przed podjęciem nauki osiągnęły odpowiedni poziom dojrzałości psychofizycznej i społecznej, przy stworzeniu właściwych warunków kształcenia, uwzględniających ich możliwości, mogą realizować obowiązek szkolny w systemie powszechnym (Dycht 2017; Paradowska 2011; Zaorska 2010). Dziecko niepełnosprawne wzrokowo natomiast, które cechuje jednocześnie obniżona sprawność intelektualna, nie jest w stanie realizować podstawy programowej kształcenia ogólnego na poziomie wymagalnym w placówkach ogólnodostępnych. Sprzężona, wieloraka niepełnosprawność w tym przypadku znacznie ogranicza możliwości poznawcze dziecka, a ogólnodostępne przedszkole czy szkoła nie są w stanie sprostać szczególnym, bardziej złożonym potrzebom podopiecznego, co stanowi argument przemawiający przeciwko jego edukacji w placówkach pracujących według modelu włączającego.

Dziecko z dysfunkcją wzroku powinno prezentować dobry poziom ogólnych sprawności sprzyjających satysfakcjonującemu przebywaniu w placówce ogólnodostępnej. Tyflolodzy zwracają uwagę na następujące umiejętności i kompetencje: samodzielność ucznia, np. samodzielność załatwiania lub przynajmniej 
sygnalizowania swoich potrzeb fizjologicznych, umiejętność samodzielnego poruszania się $\mathrm{w}$ przestrzeni, orientacja $\mathrm{w}$ środowisku społecznym (rozpoznawanie nowych ludzi), a w środowisku fizycznym - rozpoznawanie znanych miejsc, szybkie przyswajanie nowych doświadczeń, wykazywanie elastyczności i zdolności do adaptacji, umiejętność zrozumiałego wyrażania w mowie i piśmie (Majewski 2001). Niezbędna jest właściwa odporność psychiczna dziecka - w tym zakresie Aleksandra Maciarz (2005) zwraca uwagę na zdolność dziecka do komunikowania się z otoczeniem, zdolność różnicowania uczuć i emocji, umiejętność radzenia sobie z własnymi emocjami, zdolność do analizy reakcji emocjonalnych i właściwe nastawienie otoczenia wobec własnej osoby. Istotna jest także akceptacja modelu włączającego i aktywny udział ucznia w procesie edukacji i rehabilitacji (Pasterny 2012). Wszystkie te umiejętności można rozwijać i doskonalić już we wczesnym dzieciństwie, stąd tak ważne jest uczestnictwo rodziny z dzieckiem niepełnosprawnym wzrokowo $\mathrm{w}$ procesie wczesnej interwencji. Zwiększa ono dojrzałość funkcjonalną, psychiczną i społeczną dziecka, sprzyja również realizacji edukacji włączającej na jak najwyższym poziomie.

\section{Tyflologiczne przygotowanie wychowawców i nauczycieli}

Obejmuje podstawowe założenia idei włączania, wyraźnie wskazujące na to, że w systemach edukacji inkluzyjnej zmierza się do ograniczenia liczby pedagogów specjalnych w procesie wychowania i kształcenia, zatrudnionych w pełnym wymiarze godzin, obsługujących pojedynczego ucznia (gdyż żaden system szkolny nie jest w stanie zapewnić tak zróżnicowanej populacji uczniów o specjalnych potrzebach edukacyjnych [SPE], nauczycieli o odpowiednim wykształceniu, którzy potrafią sprostać różnym trudnościom rozwojowym uczniów). Zakres bezpośredniej, doraźnej, specjalnej pomocy powinien być wyraźnie zredukowany - wspólne organizowanie procesu dydaktycznego wszystkich uczniów wymaga zerwania z konwencją stałej obecności dwóch nauczycieli w grupie przedszkolnej/klasie szkolnej, co dotychczas skutkowało wyraźnym rozdzieleniem ich zadań i taką praktyką szkolną, w której nauczyciele przedmiotu pracowali z uczniami pełnosprawnymi, a pedagodzy specjalni - z podopiecznymi niepełnosprawnymi - tego typu rozwiązania były nagminnie obecne w modelu integracyjnym, i co gorsza nie przynosiły zadowalających rezultatów w grupach.

Dotychczasowe, raczej dość skromne doświadczenie kadry pedagogicznej w pracy z dziećmi/uczniami z niepełnosprawnością (w tym z dysfunkcją wzroku) w przedszkolnych i szkolnych placówkach ogólnodostępnych, skutkowało w rezultacie poczuciem braku praktycznych kompetencji zawodowych. Nauczyciele zgłaszali brak wiedzy praktycznej na temat tego, jak wdrażać idę̨ edukacji włączającej do codziennej praktyki szkolnej; jak pracować z uczniem niepełnosprawnym (w tak licznych grupach/klasach lub kiedy w jednej klasie są uczniowie o bardzo zróżnicowanych dysfunkcjach i potrzebach). Uwagi te formułowali często także pedagodzy 
pracujący według modelu integracyjnego. Również rodzice dzieci niewidomych pobierających naukę w szkołach rejonowych wielokrotnie podkreślali zauważalny często brak choćby podstawowej wiedzy nauczycieli tzw. „przedmiotowych” z tyflopedagogiki, a czasem brak chęci, aby tę wiedzę uzupełnić. Przyczyniało się to często do intuicyjnych działań pedagogicznych wobec ucznia z dysfunkcją wzroku. Rzadko się zdarzalo, że nauczyciele z własnej inicjatywy szukali kontaktu i wsparcia tyflologicznego ze strony szkół specjalnych, organizacji pozarządowych, zajmujących się edukacją i rehabilitacją osób z dysfunkcją wzroku.

W placówkach ogólnodostępnych brakuje specjalistów w zakresie tyflopedagogiki (tyflopedagogów, rehabilitantów wzroku, instruktorów orientacji przestrzennej). W celu właściwej realizacji filozofii inkluzyjnej w obszarze edukacji konieczne jest ich zatrudnienie w przedszkolach i szkołach rejonowych - w pełnym wymiarze czasu pracy lub przynajmniej na kilka, kilkanaście godzin - aby odpowiedzieć na potrzeby dzieci z dysfunkcją wzroku w zakresie zajęć rewalidacji indywidualnej.

Nowa rola pedagoga specjalnego realizującego założenia edukacji włączającej - w tym także tyflopedagoga - powinna polegać na wspieraniu wychowawców pracujących w grupach przedszkolnych czy nauczycieli klasowych oraz pełnieniu funkcji metodycznego doradcy. Jego bezpośrednia metodyczna praca z dzieckiem o zróżnicowanym rozwoju powinna być ograniczona jedynie do tych obszarów, które wymagają specjalistycznych umiejętności z zakresu rehabilitacji - np. w obrębie tyflopedagogiki powinna dotyczyć przygotowania niewidomych dzieci do nauki czytania pisma dotykowego, obecności na lekcjach, podczas których dzieci uczą się czytać i pisać alfabetem brajla, albo gdy zajęcia wymagają wykorzystania zaadaptowanych do potrzeb dziecka słabowidzącego lub niewidomego pomocy dydaktycznych i technicznych środków nauczania. Taka organizacja pracy tyflopedagoga ogranicza ilość czasu poświęconego pojedynczemu uczniowi z zaburzeniem rozwoju widzenia lub brakiem percepcji wzrokowej do kilku godzin tygodniowo w każdej grupie przedszkolnej czy klasie szkolnej. Dzięki takiemu rozwiązaniu nauczyciel może służyć specjalistycznym wsparciem kilkorgu dzieciom z niepełnosprawnością wzroku przebywającym w placówce. I analogicznie, w podobny sposób można zaaranżować pracę innych nauczycieli-terapeutów, posiadających wykształcenie w zakresie pozostałych szczegółowych subdyscyplin pedagogiki specjalnej. Specjalistyczne tyflopedagogiczne wsparcie - w zakresie orientacji przestrzennej i samodzielnego poruszania się oraz w ramach usprawniania widzenia dzieci słabowidzących mogą i powinni realizować w trakcie zajęć rewalidacji indywidualnej rehabilitanci-terapeuci odpowiednio wyszkoleni w tym zakresie - rehabilitanci wzroku i instruktorzy orientacji przestrzennej. Tych specjalistów jednak ciągle brakuje w przedszkolnych i szkolnych placówkach ogólnodostępnych, w szkolnictwie specjalnym, dla uczniów niewidomych i słabowidzących natomiast stanowią oni podstawowy filar wsparcia rehabilitacyjnego.

Właściwe zrozumienie tak pojętej idei włączania powinno przekładać się na wysokiej jakości, poprawne metodycznie zajęcia, w których podczas jednej jednostki 
dydaktycznej na najwyższym poziomie realizowana jest wzajemna współpraca nauczycieli i wychowawców przedmiotowych z kilku pedagogami specjalnymi, służącymi wsparciem dzieciom o specjalnych potrzebach rozwojowych i edukacyjnych - współpraca w zakresie posiadanych kompetencji, wzajemnej wymiany doświadczeń i dobrych praktyk. Aby ten proces mógł się powieść, konieczne są zmiany, które muszą objąć modyfikacje programów studiów wyższych na kierunkach przygotowujących przyszłych nauczycieli, mające na celu włączanie przedmiotów z zakresu pedagogiki specjalnej i zajęć metodycznych w obrębie jej szczegółowych subdyscyplin, a ponadto prowadzenie licznych kursów i szkoleń w tym zakresie.

Zmiana postaw społecznych, nastawień, przekonań w kierunku inkluzyjnym

Jednym z najważniejszych zagrożeń płynących z segregacji jest wychowanie bez rodziny. Placówki włączające mają przeciwdziałać odseparowaniu dziecka od środowiska rodzinnego, co często na okres niemal całego dzieciństwa proponują nieliczne szkoły specjalne, skupiające tylko uczniów z niepełnosprawnością wzroku. Rodzice, chcąc posłać dzieci do specjalnego przedszkola lub szkoły specjalnej dla uczniów niewidomych i słabowidzących, muszą podjąć decyzję o umieszczeniu dziecka w internacie. Skutkuje to, niestety, rzadkimi kontaktami rodzinnymi, wynikającymi z wielu różnych czynników: znacząca odległość domu od placówki edukacyjnej, utrudnione możliwości komunikacyjne. Generuje to, w konsekwencji, coraz słabsze więzi pomiędzy członkami rodziny, co wpływa wtórnie negatywnie na uczenie się pełnienia ról społecznych przez dziecko z dysfunkcją wzroku, w tym na funkcjonowanie dziecka w rodzinie i grupie rówieśniczej.

Placówki specjalne dla dzieci z niepełnosprawnością wzroku w większym niż szkoły masowe stopniu nie sprzyjają również rozwijaniu samodzielności w rozwiązywaniu trudności codziennego, rzeczywistego życia, w środowisku niekoniecznie dostosowanym do ich potrzeb i możliwości - gwarantują zaadoptowane otoczenie, specjalistyczną opiekę dostępną bez problemów, możliwość kontaktu z uczniami o podobnych trudnościach rozwoju, a tym samym dają pozorne wrażenie bezpieczeństwa, które uczy życia bez walki o siebie i swoje prawa - gdyż te mają w placówkach specjalnych całkowicie zapewnione.

Pobyt natomiast w placówce ogólnodostępnej z rówieśnikami o zróżnicowanym rozwoju generuje bardziej złożone problemy egzystencjalne i pozwala dostrzegać także możliwości i potrzeby innych, wynikające z odmiennej specyfiki ich funkcjonowania. Jednak bezsprzecznie największą zaletą edukacji uczniów z dysfunkcją wzroku w przedszkolach i szkołach ogólnodostępnych jest rzeczywiste ich włączanie w życie społeczne. Dziecko od wczesnego dzieciństwa może pozostawać w łączności z rodziną i naturalnym, lokalnym środowiskiem, uczestniczy w ich życiu, budując więzi rodzinne i rówieśnicze. 
Skuteczność inkluzji zależy w dużej mierze od własnych postaw i nastawienia osób uczestniczących w tym procesie. Prowadzi to nieodmiennie do zmiany dotychczasowych poglądów, wartościowania i stereotypów - także w obszarze edukacji - a w dalszej konsekwencji do przemiany preferowanego społecznie systemu edukacyjnego. Wymaga przełamania barier mentalnych tkwiących często w nas, dorosłych - osobach odpowiedzialnych za edukację, w nauczycielach i rodzicach. Nasze postawy przekładają się później na postawy naszych dzieci i ich wzajemne rówieśnicze relacje. Kompetentnie poinformowani w zakresie tyfloedukacji rodzice dzieci pełnosprawnych nie obawiają się ograniczenia potrzeb edukacyjnych swoich dzieci, nie podkreślają w pierwszej kolejności trudności i problemów wspólnej włączającej nauki i wychowania w poszanowaniu dobra jednostki i grupy. Zaczynają rozumieć istotę strategii normalizacji, zgodnie z którą trudności rozwojowe i odmienne potrzeby edukacyjne dziecka $z$ dysfunkcją wzroku są zauważane i uwzględniane w realizacji procesu dydaktycznego, lecz nie stanowią bariery w wykonywaniu zadań wynikających z roli ucznia. Przekazują swoim dzieciom przyjazne, pełne otwartości nastawienie społeczne, które te odzwierciedlają potem w relacjach ze swoimi niepełnosprawnymi wzrokowo rówieśnikami.

Tyfloedukacja jest podstawowym warunkiem skutecznej edukacji włączającej uczniów z dysfunkcją wzroku. Realne doświadczenie w kontaktach z człowiekiem niewidomym czy słabowidzącym uczy zrozumienia, że chodzi o spotkanie dwóch równorzędnych podmiotowych osób, $\mathrm{z}$ których każda posiada swoiste, ale tak samo ważne potrzeby rozwoju. Obie mają prawo do wspólnej przestrzeni w edukacji i obie mogą efektywnie ją kreować, w zgodzie i wzajemnym zrozumieniu. Integracja społeczna proponowana w ramach edukacji włączającej wymaga od środowisk w niej uczestniczących szczególnej troski o budowanie właściwych relacji - w atmosferze wzajemnej życzliwości, tolerancji wobec różnorodności, a przede wszystkim akceptacji podmiotowości zarówno dzieci/uczniów, jak i dorosłych - rodziców/ opiekunów, nauczycieli i innych specjalistów zaangażowanych we włączanie.

Przygotowanie infrastruktury (likwidacja barier architektonicznych, doposażenie szkół w nowoczesny sprzęt i pomoce tyflodydaktyczne)

Problem barier architektonicznych dotyczy wielu polskich szkół i przedszkoli, zwłaszcza tych, które funkcjonują w starych budynkach. Placówki te potrzebują środków finansowych na likwidację tych barier, a także na sprzęt wykorzystujący nowoczesne technologie informacyjno-komunikacyjne. Przedszkola i szkoły, w powiązaniu $z$ jednostkami samorządu terytorialnego i różnorodnymi organizacjami pozarządowymi mogą i powinny inicjować wiele działań, aby wdrożyć ideę edukacji włączającej do powszechnej praktyki.

W większości przypadków placówki ogólnodostępne nie są dostosowane do potrzeb osób z dysfunkcją wzroku. Tymczasem adaptacja sali/klasy w przedszkolu/szkole pod kątem potrzeb ucznia niewidomego czy słabowidzącego powinna 
rozpocząć się jeszcze przed przybyciem dziecka do placówki i musi być stale modyfikowana. Pod względem architektonicznym konieczne są zmiany dotyczące całego budynku, a nie tylko sali/klasy i jej najbliższego otoczenia, w których zwykle przebywa dziecko niewidome czy słabowidzące:

- aranżacja otoczenia ułatwiająca uczniom z dysfunkcją wzroku orientację $\mathrm{w}$ przestrzeni i poruszanie się,

- szlaki komunikacyjne utworzone przy zastosowaniu zróżnicowanej faktury i kontrastu,

- wyraźne elementy graficzne, np. napisy brajlowskie i napisy czarnodrukowe - duże, kontrastowe, drukowane - na drzwiach sal, na dużych przeszklonych powierzchniach, umieszczone na wysokości oczu ucznia,

- wszelkie wystające krawędzie osłonięte, filary oklejone ostrzegawczą taśmą,

- adaptacja oświetlenia,

- adaptacja pomieszczeń sanitarnych,

- przygotowane pomieszczenia pomocnicze (gabinet usprawniania widzenia, gabinet do realizacji zajęć z nauki brajla, czytania tyflografiki i realizacji ćwiczeń kompensacyjnych, gabinet czynności życia codziennego, gabinet logopedyczny i/lub do nauki alternatywnych metod komunikacji).

Zasady postępowania $\mathrm{z}$ dziećmi niewidomymi i słabowidzącymi w sali przedszkolnej i szkolnej, aranżację tego typu pomieszczenia szczegółowo opisują Barbara Kawczyńska-Reguła i Bożena Pierzchała (2001). Budynek przedszkola/szkoły i ich otoczenie powinny być $\mathrm{w}$ taki sposób dostosowane do potrzeb dzieci niewidomych i słabowidzących tak, aby dawały im szansę na rozwój, edukację i naukę samodzielności.

Problemem równie poważnym w placówce ogólnodostępnej jest niedostatek podręczników, książek, pomocy tyflodydaktycznych, brak właściwie dobranego sprzętu, ułatwiającego komunikację i edukację. Niejednokrotnie, aby inkluzja dziecka $z$ dysfunkcją wzroku się powiodła, konieczne jest ogromne zaangażowanie rodziców i placówki edukacyjnej - z praktyki pedagogicznej wynika, że przedruk w wersji brajlowskiej podręczników i książek jest zbyt późno realizowany lub jest finansowany ze środków własnych rodziców (Paplińska 2008). Zdarzają się także przypadki przepisywania podręczników przez rodzinę dziecka, gdyż ani jeden tytuł podręcznika szkolnego, z którego korzystają nauczyciele, nie ma swojej adaptacji w brajlu czy powiększonym druku. A przecież spełnienie tych wymogów należy do podstawowych obowiązków placówki włączającej. Zaniedbania tego rodzaju rzutują w konsekwencji nie tylko na funkcjonowanie poznawcze ucznia $\mathrm{z}$ dysfunkcją wzroku - skutkują w późniejszym okresie gorszym poziomem jego szeroko pojętej adaptacji społecznej. Porażką źle pojętej edukacji włączającej jest nadal fakt, że niepełnosprawni wzrokowo absolwenci placówek ogólnodostępnych nie są tak samodzielni w zakresie posługiwania się pismem brajla, samoobsługi, orientacji przestrzennej i bezpiecznego poruszania się jak uczniowie kończący szkoły specjalne, którzy otrzymali tam specjalistyczne, na wysokim poziomie wsparcie. 
Wszystko to sprawia, że nie można mówić o właściwym wyrównywaniu szans edukacyjnych dziecka/ucznia z niepełnosprawnością wzroku. Aby przedszkole czy szkoła powszechna mogły oferować dziecku z niepełnosprawnością wzroku optymalny poziom usług edukacyjnych, powinny wykorzystać dobre praktyki, stanowiące dotychczas atuty szkół specjalnych dla uczniów niewidomych i słabowidzących - tzn. sukcesywnie i systematycznie inwestować w zakup specjalistycznych pomocy tyflodydaktycznych, typu: modele $3 \mathrm{D}$, makiety, mapy, plany, rysunki dotykowe. W edukacji szkolnej przydadzą się kubarytmy, piórniki brajlowskie, narzędzia do samodzielnego kreślenia wypukłego rysunku, np. z geometrii. Potrzebny jest stale wzbogacany księgozbiór brajlowski i książki o powiększonym druku. W wyposażeniu placówki przedszkolnej i szkolnej powinny znaleźć się drukarki brajlowskie, powiększalniki komputerowe dla uczniów słabowidzących, a także inne technologie wspierające edukację uczniów z dysfunkcją wzroku. Pomocą w ich obsłudze i wykorzystaniu w pracy dydaktycznej z dzieckiem z problemem widzenia powinni służyć tyflopedagodzy zatrudnieni w szkołach rejonowych.

Placówki ogólnodostępne muszą zaproponować uczniom z dysfunkcją wzroku specjalistyczne zajęcia, niezbędne dla realizacji ich potrzeb rozwojowych: dla uczniów słabowidzących niezbędne jest wsparcie w zakresie usprawniania widzenia oraz rozwoju umiejętności efektywnego korzystania z pomocy optycznych i nieoptycznych. W zależności od potrzeb i umiejętności dzieci konieczne mogą okazać się zajęcia $z$ orientacji przestrzennej i samodzielnego poruszania się - te prowadzone są zarówno dla uczniów słabowidzących, jak i niewidomych. Oferta zajęć dodatkowych, cenionych także przez rodziców, powinna również uwzględniać zajęcia z zakresu rehabilitacji podstawowej, podczas których uczniowie opanowują umiejętności samoobsługi i czynności życia codziennego.

Cechą charakterystyczną przedszkoli i szkół ogólnodostępnych, pracujących według modelu włączającego, muszą być jak najmniej liczne grupy/klasy, co powinno być odczytywane jako spełnienie warunków bardziej skutecznego nauczania $\mathrm{i}$ indywidualizacji w pracy z uczniami ze SPE.

\section{Zbudowanie systemu wsparcia dla dziecka/ucznia z niepełnosprawnością wzroku w przedszkolu/szkole (zaangażowanie wszystkich podmiotów)}

Istnieją okoliczności, w których nie indywidualne ograniczenia, lecz zewnętrzne przeszkody utrudniają człowiekowi uczestnictwo w życiu, czynią go niepełnosprawnym. Osoby z niepełnosprawnością „będą uzyskiwać niezbędne wsparcie, w ramach powszechnego systemu edukacji, celem ułatwienia ich skutecznej edukacji” (Konwencja ONZ, art. 24, pkt. 2d - Dz.U. z 2012 roku, poz. 1169, s. 13). Dlatego konieczne jest stworzenie w placówkach powszechnych takiego klimatu kulturowego, który pozwoli im bardziej elastycznie odpowiadać na potrzeby wszystkich dzieci danej społeczności (Ainscow 200o, s. 188). Jest to zadanie dla nas wszystkich: 
samorządowców, dyrektorów szkół, nauczycieli, rodziców i pozostałych członków lokalnych społeczności.

Uczeń o zróżnicowanym rozwoju ze względu na słaby wzrok w szkole ogólnodostępnej potrzebuje zapewnienia odpowiedniego wsparcia, w które zaangażowane powinno być całe lokalne środowisko. Szczególne zadania w tym zakresie mają jednostki samorządu terytorialnego. Częsta i dobra współpraca przedszkola i szkoły z jednostkami administracji samorządowej, z poradnią psychologiczno-pedagogiczną, współpraca z innymi instytucjami działającymi na rzecz osób niepełnosprawnych wzrokowo zapewni stworzenie oferty edukacyjnej dla ucznia z dysfunkcją wzroku na najwyższym, optymalnym dla jego potrzeb poziomie. Systematyczność takiego współdziałania z pewnością rzutuje pozytywnie na jakość proponowanej edukacji, i odwrotnie - okazjonalność tej współpracy lub całkowity jej brak utrudnia lub blokuje rozwój edukacji włączającej w odniesieniu do uczniów $\mathrm{z}$ dysfunkcją wzroku.

\section{Konkuzje}

„Inkluzja może łączyć, ale może też dzielić, szczególnie gdy w fazie konstytuowania się tendencji pojawiają się życzeniowe założenia. Pierwsze może wynikać z przeświadczenia/nadziei, że jako społeczeństwo jesteśmy gotowi na inkluzję. Drugie, że posiadamy zaplecze w postaci wykwalifikowanej kadry, mogącej sprostać wyzwaniu pracy w zespole heterogenicznym. Trzecie, że efekty kształcenia inkluzyjnego niepełnosprawnych będą lepsze niż w innych formach" - pisze Iwona Chrzanowska (2014, s. 112), zwracając uwagę na pułapkę fałszywego złudzenia o prostocie i łatwości realizacji włączającego kształcenia, w którym bagatelizowane są trudności natury finansowej, organizacyjnej i kadrowej, wpływające na iluzoryczność tego dynamizmu.

Edukacja włączająca - właściwie pojęta i zorganizowana - umożliwia częsty kontakt dzieci o zróżnicowanym rozwoju, pozostanie w naturalnym środowisku rodzinnym, podnoszenie u dzieci z niepełnosprawnością poziomu motywacji, aktywności życiowej i sprawności komunikacyjnej. Wreszcie, sprzyja budowaniu świadomości inkluzyjnej społeczeństwa, zwłaszcza młodego pokolenia, które w przyszłości tworzyć będzie regulacje prawne, legislacyjne, gospodarcze i społeczne i budować relacje prowłączające, w naturalny sposób wdrażając główne założenia idei inkluzji.

Powyżej omówione czynniki znacząco rzutują na poczucie jakości realizacji zobowiązań w obrębie edukacji włączającej dzieci z dysfunkcją wzroku i stanowią swoiste wyzwanie dla współczesnej pedagogiki przedszkolnej i szkolnej w obszarach:

- tyflodydaktyki i metodyki kształcenia, znajdujących zastosowanie w systemach włączających,

- organizacji procesu kształcenia z uwzględnieniem tyfloadaptacji infrastrukturalnych, 
- $\quad$ stworzenia sprzyjającej atmosfery społecznej, umożliwiającej zmianę negatywnych nastawień, przekonań, przyzwyczajeń i postaw społecznych, barier otoczenia społecznego wobec osób z problemami widzenia w kierunku akceptacji społeczeństw inkluzyjnych,

- zbudowanie systemu zespołowego wsparcia i współpracy wszystkich specjalistów i instytucji świadczących pomoc w zakresie opieki, edukacji i rehabilitacji dzieci zróżnicowanych rozwojowo ze względu na wzrok, z podkreśleniem roli WWRD jako modelu przygotowującego rodzinę i dziecko niewidome lub słabowidzące do uczestnictwa w edukacji włączającej.

\section{Bibliografia}

Ainscow M. (200o). Robić właściwe rzeczy. Potrzeby specjalne z perspektywy doskonalenia szkoły. W: Fairbairn G., Fairbairn S. (red.). Integracja dzieci o specjalnych potrzebach. Wybrane zagadnienia etyczne. Warszawa: CMPP-P.

Barańska M. (2007). Jak informować rodziców o stwierdzonych u dziecka nieprawidłowościach rozwojowych - psychologiczne konsekwencje niepomyślnej diagnozy. W: Kwaśniewska G. (red.). Interdyscyplinarność procesu wczesnej interwencji wobec dziecka i jego rodziny. Lublin: Wydawnictwo UMCS.

Chrzanowska I. (2014). Nauczanie inkluzyjne $w$ doświadczeniach polskich - podstawy prawne i społeczne uwarunkowania. „Studia Edukacyjne”, nr 30, s. 109-117.

Czerwińska K. (2016). Środowisko rodzinne małego dziecka z niepełnosprawnością wzroku. W: Czerwińska K. (red.). Wybrane aspekty rozwoju małego dziecka $z$ niepetnosprawnościa wzroku. Warszawa: Wydawnictwo APS.

Czerwińska K., Dąbrowska I. (2015). Rodzice i specjaliści w procesie wczesnego wspomagania rozwoju dzieci niewidomych i słabowidzacych. W: Czerwińska K. (red.). Wczesne wspomaganie rozwoju dziecka $z$ niepełnosprawnościq wzroku: w kręgu diagnozy i terapii. Warszawa: Wydawnictwo APS.

Dycht M. (2015). Edukacja włączająca uczniów z dysfunkcja wzroku w Polsce wdrażanie zobowiązań i analiza wątków zaniedbanych. „Niepełnosprawność i Rehabilitacja”, nr 2, s. 34-49.

Dycht M. (2017). Edukacja i wspieranie uczniów ze specjalnymi potrzebami edukacyjnymi i rozwojowymi w placówkach oświatowych $w$ Polsce. W: Śmiechowska-Petrovskij E. (red.). Dzieci z trudnościami rozwojowymi w młodszym wieku szkolnym. Indywidualne programy edukacyjno-terapeutyczne $w$ procesie wspierania dzieci. Warszawa: Wydawnictwo Naukowe UKSW.

Finding Out about Blindness - Teacher's Pack. Program wychowawczy sprzyjający integracji społecznej dzieci niewidomych (1991). London: Royal National Institute of The Blind.

Firkowska-Mankiewicz A. (2004). Edukacja włączająca - wyzwaniem dla polskiej szkoły. „Szkoła Specjalna”, nr 1, s. 19-26. 
Kawczyńska-Reguła B., Pierzchała B. (2001). Zagadnienia nauczania początkowego dzieci z dysfunkcja wzroku. W: Poradnik dydaktyczny dla nauczycieli realizujacych podstawe programowa $w$ zakresie szkoły podstawowej i gimnazjum z uczniami niewidomymi i słabo widzacymi. Warszawa: MEN.

Kirenko J., Grindrich P. (2007). Odkrywanie niepetnosprawności wzrokowej w nauczaniu właczającym. Lublin: Wydawnictwo Akademickie WSSP.

Konarska J. (2010). Rozwój i wychowanie rehabilitujące dziecka niewidzącego w okresie wczesnego i średniego dzieciństwa. Kraków: Wydawnictwo Naukowe UP.

Konwencja praw osób niepełnosprawnych. (2006). Art. 24, pkt. 2d. Nowy Jork: ONZ. (Dz.U. z 2012 roku, poz. 1169).

Kuczyńska-Kwapisz J. (2014). Wczesne wspomaganie rozwoju dzieci niewidomych i edukacja tyflopedagogiczna ich rodzin na przykładzie projektu „Międzynarodowa Szkoła Matek”. „Forum Pedagogiczne”, nr 2, s. 45-59.

Lechta V. (2010). Pedagogika inkluzyjna. W: Śliwerski B. (red.). Pedagogika. T. 4: Subdyscypliny i dziedziny wiedzy o edukacji. Gdańsk: GWP.

Maciarz A. (2005). Integracja edukacyjna w świetle doświadczeń i oczekiwań dzieci niepełnosprawnych. W: Pilecka W., Ozga A., Kurtek P. (red.). Dziecko ze specjalnymi potrzebami edukacyjnymi w ekosystemie. Kielce: Wydawnictwo AŚ.

Majewski T. (2001). Dzieci z uszkodzonym wzrokiem i ich edukacja. W: Jakubowski S. (red.). Poradnik dydaktyczny dla nauczycieli realizujacych podstawe programowa w zakresie szkoły podstawowej i gimnazjum z uczniami niewidomymi i słabo widzącymi. Warszawa: MEN.

Orkan-Łęcka M. (2003). Mama, tata, dziecko, czyli o tym, jak uczyć małe niewidome dziecko w warunkach domowych. Warszawa: PZN.

Paplińska M. (2008). Dziecko z niepetnosprawnością wzrokową na progu szkoły - przygotowania, możliwości i realne wsparcie. W: Gorajewska D. (red.). Wspomaganie dziecka $z$ niepetnosprawnościa $w$ rodzinie i szkole. Warszawa: Stowarzyszenie Przyjaciół Integracji.

Paplińska M., Witczak-Nowotna J. (2015). Tyfloedukacja jako element budowania integracji społecznej uczniów niewidomych i słabowidzacych $w$ edukacji włączającej. W: Czerwińska K., Paplińska M., Walkiewicz-Krutak M. (red.). Tyflopedagogika wobec współczesnej przestrzeni edukacyjno-rehabilitacyjnej. Warszawa: Wydawnictwo APS.

Paradowska E. (2011). Praca z dzieckiem głuchoniewidomym. W: Głodkowska J. (red.). Uczeń ze specjalnymi potrzebami edukacyjnymi w szkole ogólnodostępnej. Warszawa: Wydawnictwo APS.

Pasterny H. (2012). Uczeń niewidomy w szkole masowej - wyzwania integracji. W: Praca z uczniem o specjalnych potrzebach edukacyjnych. Guza A., Krzyżyk D. (red.). Kielce: Wydawnictwo Pedagogiczne ZNP.

Pisula E. (2007). Informowanie rodziców o zaburzeniach w rozwoju dziecka. W: Pisula E. (red.). Rodzice i rodzeństwo dzieci z zaburzeniami rozwoju. Warszawa: Wydawnictwo UW. 
Sekułowicz M. (2017). Rola edukacji włączającej w podnoszeniu jakości edukacji wszystkich uczniów. Wojewódzka konferencja pt. „Wsparcie uczniów ze specjalnymi potrzebami edukacyjnymi i upowszechnianie edukacji włączającej”, Świdnica, 4 grudnia 2017 r., dostępny na: https://www.kuratorium.wroclaw.pl/ wp-content/uploads/2017/12/rola-edukacji-wlaczajacej-w-podnoszeniu-jakosci-edukacji-wszystkich.pdf (otwarto: 8.01.2017).

Sińska J. (2006). Matka i dziecko z uszkodzonym wzrokiem - transakcyjny model wspomagania interakcji. W: Gałkowski T., Pisula E. (red.). Psychologia rehabilitacyjna. Wybrane zagadnienia. Warszawa: Wydawnictwo Instytutu Psychologii PAN.

Skoczylas E. (2013). Wspieranie rodzin dzieci z dysfunkcją wzroku. W: Sidor-Piekarska B. (red.). Kompetentne wspieranie rodzin z niepełnosprawnością. Lublin: KUL.

Speck O. (2005). Niepełnosprawni w społeczeństwie. Podstawy ortopedagogiki. Gdańsk: GWP.

Speck O. (2013). Inkluzja edukacyjna a pedagogika lecznicza. Gdańsk: Wydawnictwo Harmonia.

Szumski G. (2010). Wokół edukacji włączającej. Warszawa: Wydawnictwo APS.

Szumski G. (2011). Teoretyczne implikacje koncepcji edukacji właczajacej. W: Z. Gajdzica (red.). Uczeń z niepełnosprawnościa w szkole ogólnodostępnej. Sosnowiec: Oficyna Wydawnicza „Humanitas”.

Urmańska W. (2007). Wczesna interwencja psychologiczna w procesie uczenia sie rodzicielstwa. W: Kwaśniewska G. (red.). Interdyscyplinarność procesu wczesnej interwencji wobec dziecka i jego rodziny. Lublin: Wydawnictwo UMCS.

Walkiewicz M. (2005). Model programu wspomagania rozwoju widzenia dzieci z zaburzeniami widzenia. „Szkoła Specjalna”, nr 2, s. 126-139.

Wawrowska E. (2011). W rodzinie niewidomego dziecka. W: Liberska H. (red.). Rodzina $z$ dzieckiem niepełnosprawnym - możliwości i ograniczenia rozwoju. Warszawa: Difin.

Zaorska M. (2010). Edukacja i rehabilitacja osób głuchoniewidomych w Polsce i Rosji (rozwój i stan obecny). Toruń: UMK. 


\title{
CONTEMPORARY CHALLENGES OF PRE-SCHOOL AND SCHOOL PEDAGOGY IN THE FIELD OF EDUCATION INCLUDING BLIND AND VISUALLY IMPAIRED CHILDREN
}

\begin{abstract}
The article aims to present a model of education involving blind and visually impaired children in pre-school and school institutions in accordance with the strategy of standardization and the objectives of contemporary pedagogy for visual impairment. The paper explains the importance of basic didactic-methodological, organizational and social conditions and also underlines the role of early development support for the quality of inclusion of children with visual disabilities in the public education system.
\end{abstract}

Keywords: child, sight disability, inclusive education, kindergarten, school.

Marzena Dycht - profesor nadzwyczajny na Wydziale Nauk Pedagogicznych UKSW w Warszawie, doktor habilitowany nauk społecznych. Tyflopedagog. Autorka czterech publikacji naukowych i wielu artykułów polskich i zagranicznych z zakresu pedagogiki specjalnej i szczegółowej jej subdyscypliny - tyflopedagogiki. Udział w projekcie „Podnoszenie kompetencji nauczycielskich w pracy z uczniem o specjalnych potrzebach edukacyjnych - kwalifikacyjne studia podyplomowe dla nauczycieli szkół ogólnodostępnych", Nr RPMA.10.03.04-14-1902/15. Koordynator (2016). Główny wykonawca (2016-2018). Kierownik studiów podyplomowych „Pedagogika Osób z Niepełnosprawnością Intelektualną i Tyflopedagogika” na WNP UKSW. Członek Zespołu Pedagogiki Specjalnej Polskiej Akademii Nauk. Adres do korespondencji: Wydział Nauk Pedagogicznych UKSW, ul. Wóycickiego 1/3, o1-938 Warszawa. Adres e-mailowy: m.dycht@uksw.edu.pl. 